\title{
Spiritualiteit te midde van 'n kultuur van voorspoed. 'n Fokus op die Ooste van Pretoria
}

\author{
J Müller \& W de Koker ${ }^{1}$ \\ (Universiteit van Pretoria)
}

\begin{abstract}
Spirituality in an affluent culture. A focus on the Eastern suburbs of Pretoria
\end{abstract}

The eastern suburbs of Pretoria is a white, mainly Afrikaans speaking and Dutch Reformed community with a relatively high level of education and income and a mostly stable family life. Religion is important to most of the inhabitants. Church life is characterised by movement and change. Church members move to and fro between different churches and congregations, while many congregations experience change in their worship services. This leads to pain and schism in congregations, and members experience marginalisation. The research has been done by listening to the stories of individuals (co-researchers). The story of the research has developed under the themes of leadership, so called "American" and "European" attitudes towards life, change, relationships and service. The story reaches a climax when the predominant attitudes of prosperity and success is deconstructed in values that are shared by all the co-researchers, namely worship, care and service.

\section{AGTERGROND EN MOTIVERING VIR DIE ONDERSOEK}

Die Diensraad van die Sinode van Oos-Transvaal van die NG Kerk het die tendens waargeneem dat daar ' $n$ merkbare mobiliteit bestaan ten opsigte van kerkbetrokkenheid en affiliasie aan denominasies in die Ooste van Pretoria. Dit was selfs vir hulle nodig om gesprekke te voer met groepe lidmate wat ontevrede is met die algemene spiritualiteit in sekere gemeentes. Daar is ook kennis geneem van sommige lidmate wat die lidmaatskap van die hoofstroomkerke verruil vir meer charismatiese groepe. Dit was die motivering vir die versoek aan die twee skrywers om 'n navorsingsprojek van stapel te stuur om te probeer vasstel wat die aard van die tendense is.

\footnotetext{
1 Die twee skrywers is altwee verbonde aan die Departement Praktiese Teologie, Universiteit van Pretoria. Julian Müller is hoof van die Departement en Willie de Koker is op ' $n$ tydelik-deeltydse basis verbonde as navorsingsassosiaat. Die navorsing wat in hierdie artikel gerapporteer word is gesamentlik aangepak, maar Willie de Koker was die veldwerker en daarom verwys die eerste persoon telkens na hom.
} 
$\mathrm{Ek}^{2}$ het gaan luister na die verhale van ' $\mathrm{n}$ aantal lidmate en predikante in gemeentes in die ooste van Pretoria, en in hierdie artikel (navorsingsverslag) vertel ek wat ek gehoor het. Ek vertel nie maar net klakkeloos en onnadenkend oor nie. Wetenskaplike navorsing behels die voortdurende luister en interpreteer van verhale. Ek kan dit nie objektief doen nie, want ek interpreteer die verhale vanuit my eie lewenswêreld en ervarings (Lieblich, Tuval-Maschiach en Zilber 1998:10). Omdat ek deel is van die konteks waarbinne die navorsing plaasvind, skryf ek in die eerste persoon. Ek is 'n predikant in 'n gemeente wat ook in die Ooste van Pretoria geleë is (NG Kerk Lynnwood). Ek het binne die konteks van die gemeente waarin ek werk 'n bewuste keuse gemaak vir 'n tipe spiritualiteit wat aansluiting vind by 'n meer formele styl van aanbidding in die erediens. Die gemeente is 'n groot gemeente, met ses voltydse predikante. Ons het in die vroeë negentigerjare gekies vir 'n tipe bedieningsmodel wat probeer om ruimte te skep vir lidmate se verskillende behoeftes ten opsigte van ouderdom en spiritualiteit.

\section{METODIEK VAN DIE NAVORSING}

Hierdie navorsing word vanuit en binne die sosiaal-konstruksionistiese paradigma aangepak. Ons as navorsers is, op grond van hierdie paradigma, daarop ingestel om ook in diens te staan van ons gespreksgenote. Vir ons is hulle nie "objekte" nie, maar mede-navorsers en daarom is dit ook ons wens dat die navorsing tot voordeel van ons gespreksgenote sal verloop. Ons aanvaar dat navorsingsresultate nie konteksloos as absolute waarhede vir alle mense en situasies geldig is nie. Inteendeel, ons posisioneer ons op dieselfde manier as Pattison, $\mathrm{S}$ and Woodward, J (1994):

Pastoral theology (practical theology - J M \& W de K) at its best, like cultural anthropology, is probably a small scale enterprise, which pays minute attention to particular situations and is more remarkable 'for the delicacy of its distinctions not the sweep of its abstractions' (Geertz 1991, 25). It needs to pay minute attention to seeing and understanding a particular phenomenon and to listen before moving into carefully chosen words. Contextually and situationally sensitive pastoral theologies will be modest in their claims and assertions. This is a welcome feature amidst the past grandiosity of many theological enterprises which have sought to control and order the world rather

\footnotetext{
${ }^{2}$ In hierdie artikel word afwisselend van die eerste persoon enkelvoud en meervoud gebruik gemaak. Die “ons” verwys na die twee skrywers en die "ek” verwys telkens na dr Willie de Koker wat die persoon was wat die onderhoude gevoer het.
} 
than to understand it and to set particular individuals and communities free. (Willows, D and Swinton, J (eds) 2000:42)

Hoewel ons nie algemeen geldende uitsprake wil maak nie, en alhoewel ons lojaal wil wees teenoor ons mede-navorsers, is dit ook so dat alle wetenskaplike aktiwiteit ' $n$ kritiese doel het. Binne die paradigma van die sosiale-konstruksionisme sou ons kon praat van 'n dekonstruktiewe doel: "(It) is an approach to human inquiry that encompasses a critical stance in relation to taken-for-granted assumptions about the social world, which are seen as reinforcing the interests of dominant social groups and a belief that the way we understand the world is a product of a historical process of interaction and negotiation between groups of people” (Mcleod 1999). Daarom word daar in hierdie navorsing ook klem gelê op die metanarratiewe of die diskoerse wat beslis ook ' $n$ invloed op mense se spiritualiteit uitoefen.

Hierdie navorsing word gestruktureer op die basis van die metafoor van die skryf van fiksie, soos ontwikkel in 'n artikel van Müller, Van Deventer en Human (2001). Verhale, ook navorsingsverhale soos hierdie, ontwikkel langs die volgende lyne: aksie, agtergrond, ontwikkeling, klimaks en ' $\mathrm{n}$ einde (Action, Background, Development, Climax and Ending. Kortweg: Die ABDCE-benadering). Die navorsing bestudeer nie net verhale nie, dit is self ook ' $n$ verhaal (Lieblich, Tuval-Maschiach en Zilber 1998:21; Ceglowski 2000:88), wat geskryf word deur al die persone wat aan die navorsing deelneem - hetsy deurdat hulle hulle eie verhale vertel of deurdat hulle na ander mense se verhale luister. Die navorsing bied dus nie noodwendig oplossings vir ' $\mathrm{n}$ probleem nie. Dit vertel eerder, en dit betrek die deelnemers aan die aksie om die verhaal verder te skryf. Al vertellende word heersende diskoerse belig en gedekonstrueer.

Ek het die persone na wie se verhale ek geluister het, soos volg opgespoor: Eers het ek die skribas van drie NG Kerk ringe in die ooste van Pretoria gevra om elkeen vir my twee gemeentes te noem, waarvan een se eredienste as meer "tradisioneel" of "gereformeerd" en 'n ander se eredienste as meer "vernuwend" of "charismaties" beskou sou kon word. In hierdie gemeentes het ek die predikante genader om hulle verhale vir my te vertel, en om vir my lidmate se name te gee wat besonder gelukkig of ongelukkig is met hulle gemeentes se eredienste en spiritualiteit. Die gesprekke is op band geneem en verbatim oorgetik.

\section{AKSIE}

“Ek was so geskok. Ek het in my eie kerk vreemd gevoel. Toe ek by die deur uitstap, het ek omgedraai en weer na die naambordjie gekyk. Ek wou seker 
maak dis nie 'n droom nie. Die woorde het lewensgroot na my geroep. Nederduitse Gereformeerde Kerk.”

Hierdie lidmaat se ervaring roep baie vrae na vore. Waarom het bykans elke NG gemeente ' $n$ eie unieke styl van aanbidding in die erediens? Waarom is daar gemeentes wat voortgaan om 'n unieke styl te ontwikkel, al moet hulle lidmate na ander gemeentes en kerke afstaan? Is dit goed dat dit so is? Mag dit so wees? Watter styl is die beste? Is al die verandering nie maar net vervlakking nie, of is dit vernuwende verdieping?

Geen navorsing sal op hierdie vrae klinkklare antwoorde kan gee waarmee almal hulleself kan vereenselwig nie. Die gevaar bestaan eerder dat sulke navorsing lidmate, gemeentes en predikante nog meer in kampe gaan verdeel. Een predikantespan het dit onomwonde vir my gesê:

"Ek dink jy hoor, ons is nie gemotiveer om vreeslik hierby betrokke te raak nie, jy hoor ook, ons sien nie vreeslik sin in waarmee jy besig is nie, of dit regtig ' $n$ geestelik opbouende moment gaan wees in die kerk en in die koninkryk, maar as jy hierdie saak en julle het hierdie saak uitgemaak, jy en Julian het vrede hieroor, en die sinode is agter jou, wil ons graag saam werk, en as ons ' $n$ bydrae kan lewer, dan wil ons graag saam werk, maar dan gaan dit oor die opbou van die kerk, as dit gaan oor 'n stryery oor spiritualiteit dan is ons uit. As dit gaan oor dat een tipe spiritualiteit beter is as ' $n$ ander, en dat daar verdenking oor sekere spiritualiteite geplaas word, en ons weer die kerk wil begin in boks in ' $\mathrm{n}$ rigting, dan wil ons nie in daardie gesprek deelneem nie, want ons het 'n passie vir die kerk om te groei, en om uit die dood uit op te staan,...”

Die aksieveld waarbinne die verhaal afspeel, is vol beweging en verandering. Die volgende bewegings en veranderinge vind in gemeentes in die ooste van Pretoria plaas:

1 Lidmate beweeg van kerklike betrokkenheid na kerklosheid en kerkloosheid. Dit beteken nie noodwendig dat hierdie mense ongelowig raak nie - baie mense hou steeds deur Bybelstudie of gebed 'n persoonlike verhouding met God in stand.

2 Lidmate beweeg van oppervlakkige godsdienstigheid na intense toewyding aan God en meelewing in die gemeentelike lewe. Een dominee vertel die volgende verhaal:

“' $n$ Baie kritiese belangrike ding in die gemeente is, dat ons op ' $n$ gemiddelde week enige iets van tien tot dertige mense sien tot bekering kom...... so ons groei is nie net geografies nie en geboorte groei nie, dit is bekerings groei. En daardie bekerings groei, dit dwing jou, dit is altyd nuwe lewe wat kom, dit dwing jou om hierdie mense te akkommodeer en strukture te skep wat die nuwe mense kan inkom, en hulle bring nuwe 
invloed in, en dit bevry die gemeente, en ek persoonlik dink dit is een van die goed wat net gebeur, want mense verstaan nie later wat die impak, of dat ons vergeet die impak daarvan op die gemeente, en dit is wat deel van die vernuwing, dis vernuwend, dis nuwe ouens wat by kom, dit is wat jy wil hê, dit is waarvoor die kerk daar is, mense wat tot bekering kom, so daar het 'n mentaliteits verskuiwing gekom, waarin jy 'n klomp gemeentes het wat in ' $n$ oorlewingsstryd is, en in "maintenance mode" is, is hier 'n goeie ding, ek kan nie dink wanneer laas, ek kan nie dink dat ek in die afgelope drie jaar wat ek hier is, ek is bietjie langer by die gemeente betrokke, ek kan nie onthou dat ek een keer by iemand gehoor het, of gepraat het, wat in die afgelope vyf jaar in die gemeente, wat praat van stagneer, of ons moet net ons eie hou, ons moet nou net pasop dat alles nie doodloop nie, ons moet nou keer nie. Ons probleem is, hoe gaan ons ruimte maak vir die groei, so dit is 'n mentaliteit in jou kop, wat jy sê, kom ons beweeg, in plaas van om te sê, luister, laat ons net eers kyk waar ons die kant drade kan span, dat iemand nie nou nog kom en steel by ons nie.”

3 Lidmate beweeg ook heen en weer tussen verskillende gemeentes. Party lidmate bly lidmate van die NG Kerk, maar hulle gaan oor na ander gemeentes waarmee hulle hulleself meer kan vereenselwig. Hierdie verkeer is nie net ' $n$ eenrigting verkeer na sogenaamde charismatiese gemeentes en kerke nie - ek het geluister na verhale van mense wat juis vanaf die meer charismatiese gemeentes en kerke na meer gereformeerde gemeentes en kerke oorgegaan het. Ander lidmate verkies egter om steeds in hulle gemeentes te bly, al stem hulle nie saam met die rigting wat die gemeente inslaan nie.

4 Gemeentes beweeg vanaf ' $n$ formele eredienstyl met meer vaste liturgiese ordes, musiekstyle, kleredrag en teologiese taal na 'n meer informele en spontane eredienstyl. Die verskillende elemente van die liturgiese orde word voortdurend op nuwe maniere ingeklee en in verskillende volgordes geplaas, lidmate neem meer verantwoordelikheid vir die beplanning van die eredienste en meer eietydse musiek word gebruik.

5 Daar is ook gemeentes wat spesifiek gekies het om die meer tradisionele erediensstyle te behou. Dit kan nie net as tradisionalistiese formalisme beskou word nie. Lidmate word begelei om te verstaan waarom die verskillende liturgiese elemente in die erediens opgeneem is en om elke element sinvol te ervaar. Hierdie gemeentes se keuse weerspieel ook verandering en beweging.

6 Die verandering in erediensstyle weerspieel hoofsaaklik ' $n$ verandering in die teologiese identiteit van die gemeentes. Alle aktiwiteite van die gemeentes (omgeegroepe, persoonlike huisbesoek, uitreikaksies, kategese, ens) word beïnvloed deur die erediensstyl 
waarvoor die gemeentes gekies het. Ander oorwegings speel egter ook ' $n$ rol, bv lidmate se behoeftes (baie keer meer spesifiek die jongmense se behoeftes), leiers se teologiese oortuigings, en finansiële oorwegings (veral by kleiner gemeentes wat net een predikant het).

Die verandering gebeur natuurlik nie net vanself nie. Baie gemeenteleiers en lidmate wil dit so hê:

Ek dink as mens verder wil praat oor die groei in hierdie gemeente moet ons nie vergeet van die fisiese gebou nie, die opset van die gebou nie, dit lyk nie soos ' $n$ kerk nie, soos ' $n$ tradisionele kerk nie, die auditorium waarin mense instap is die wêreld wat hulle vandag ken, in die 21ste eeu, dit is nie negentien honderd en iets se gebou nie, dit lyk nie asof jy in 'n ossewa gaan kerk hou nie. Die gebou skep 'n gees, ' $n$ bepaalde klimaat vir verandering, dit kan nie dit, jy kan altyd alternatiewelik dink in die gebou, omdat ons nie in mekaar se agterkop sit en vaskyk nie.

Ek het vir ' $n$ baie lang tyd, ek dink baie ouens besef dit wat net die gebou doen, dat ons sit met ' $n$ geboue strukture waar ouens vas gevang is in die gebou, en jy het hom probeer vernuwe, maar jy kan amper nie gaan nie omdat die struktuur jou vas hou, en ek sien dit op 'n klomp plekke, en die oomblik as jou gebou fisies so gebou word dat hy in die denkraamwerk van vandag se mense is, dan kan hy anders dink ook. Net die fisiese kompleks.

Die beweging en verandering is nie net ' $n$ kerklike verskynsel nie. Dit weerspieel iets van die samelewing waarin ons leef. Hieroor vertel ons meer in die tweede beweging van die verhaal.

\section{AGTERGROND}

Die ooste van Pretoria is vir die doeleindes van hierdie studie begrens tot die woongebiede aan die oostekant van die Pietersburg snelweg, vanaf Elarduspark en Pierre van Reyneveld in die suide tot by Silverton in die noorde. Behalwe Silverton, is die meeste van hierdie woongebiede betreklik onlangs (vanaf 1970) as woongebiede ontwikkel. Dit word veral bewoon deur mense wat hulleself in die hoër sosio-ekonomiese lae van die samelewing bevind. 'n Groot persentasie van die mense het naskoolse onderwys ontvang en beoefen witboordjie en professionele beroepe. Alhoewel daar baie jongmense woon, is daar ook baie mense in die hoër ouderdomsgroepe.

Die volgende statistiek uit die nasionale sensus wat in 1996 deur Statistiek SA geneem is, is belangrik om meer van die oostelike gebied in Pretoria te verstaan:

- $\quad 73.7 \%$ van die 84324 mense in die ooste van Pretoria wat deur die sensusopname geregistreer is, is onder 45 jaar oud. 
- $\quad 66,32 \%$ van hierdie mense se eerste spreektaal is Afrikaans, en $21,38 \%$ se eerste spreektaal is Engels. Landswyd is slegs $14,3 \%$ van die land se bevolking se eerste spreektaal Afrikaans, en 6,6\% Engels.

- $\quad 4,51 \%$ van die mense in die ooste van Pretoria beoefen geen godsdiens nie, terwyl $94,42 \%$ van die mense aangedui het dat hulle Christene is. Landswyd is slegs $74,1 \%$ van die bevolking Christene, en $18,3 \%$ is agnosties of verstrek nie hulle geloofsverband nie.

- $\quad 50,6 \%$ van die christene in die ooste van Pretoria behoort aan die NG Kerk, 18,3\% aan ander gereformeerde kerke, 8,7\% aan pentekostalistiese en charismatiese kerke, 6,4\% aan die Katolieke en Grieks-Ortodokse kerke en $16 \%$ aan ander kerke. Landswyd het $11,7 \%$ van die totale aantal christene en $41,4 \%$ van die blanke christene in 1996 aan die NG Kerk behoort, terwyl 8,9\% van die totale aantal christene en $11,4 \%$ van die blanke christene aan pentekostalistiese en charismatiese kerke behoort het.

- Van die totale bevolking (kinders ingesluit) in die ooste van Pretoria het 30,3\% matriek en 'n ander kwalifikasie (sertifikaat, diploma of graad) behaal, terwyl 18,5\% matriek en 'n graad behaal het. Van die mense wat reeds matriek behaal het, het $31,24 \%$ ook 'n graad agter die naam.

- $\quad$ Van die 43709 mense uit die Ooste van Pretoria wat aangedui het dat hulle 'n beroep beoefen, val:

$>12,31 \%$ in die kategorie "Legislators, senior officials and managers";

$>\quad 25,35 \%$; in die kategorie "Professionals" en

$>13,02 \%$ in die kategorie "Technicians and associate professionals".

- Van die totale bevolking (kinders ingesluit) in die ooste van Pretoria het 20,88\% meer as R6 000 per maand verdien. Indien hierdie syfer met 7\% per jaar aangepas word na 2002, is dit R9 001 per maand.

- Van die totale bevolking (kinders ingesluit) in die ooste van Pretoria is $42,13 \%$ ongetroud, $47,31 \%$ getroud, 3,83\% leef in weduskap, $2,01 \%$ woon saam en $4,72 \%$ is geskei. (Die ongewoon lae syfer kan toegeskryf word daaraan dat die sensusdata nie gevra het na hertrou en hersaamgestelde gesinne nie.) 
Uit die 1996 syfers kom dus ' $\mathrm{n}$ beeld na vore van ' $\mathrm{n}$ wit, oorwegend Afrikaanssprekende en NG gemeenskap met ' $n$ relatief hö̈ opvoedingspeil, goeie inkomste en 'n stabiele gesinslewe. Tog moet die volgende opmerkings bygevoeg word: Uit ' $n$ gesprek met me Petro Barnard, 'n maatskaplike werker wat die afgelope meer as tien jaar intensiewe groepsterapie met tieners in die ooste van Pretoria doen, blyk dit egter dat tieners in hierdie gebied al hoe meer met dwelms eksperimenteer en ook al hoe meer selfmoord gedagtes koester. By een skool in die ooste van Pretoria was daar in 2001 vier pogings tot selfmoord, waarvan twee geslaag het. Barnard skryf dit daaraan toe dat tieners dikwels nie hegte en betekenisvolle gesinsverhoudings het nie, dat hulle eensaam is en dat hulle aan geweldige druk blootgestel is. Een tiener stel dit soos volg:

"My maats is besig om te vou onder die druk, die akademiese druk, die druk wat hulle ouers op hulle plaas, die keuring en so aan. Ons soek iemand om mee te praat wat nie maar net nog 'n maat is nie, want ons maats sit met dieselfde druk as ons”.

In Barnard se woorde: "Hier is mense wat trauma beleef - weekliks".

Die huidige samelewing word veral gekenmerk deur individualisme en pluralisme. Daar is nie meer regte of verkeerde antwoorde nie. Dit skep ruimte vir gemeentes en individuele lidmate om standpunte te handhaaf en hulle godsdiens uit te leef op maniere wat nie noodwendig ooreenstem met dié van die kerklike tradisie of die breër gemeenskap nie. Die kerklike toneel in die ooste van Pretoria, soos ons dit hierbo beskryf het, sê ook iets van die sosiaal-ekonomiese wêreld waarbinne die inwoners van die gebied lewe. Verandering, persoonlike keusevryheid en ' $\mathrm{n}$ strewe na sukses, wat gemeet word deur finansiële voorspoed, luukse besittings en beroepsprestasies, is aan die orde van die dag. Hierdie strewe na sukses vind ook neerslag in die kerklike lewe:

“... want dit is ons passie, om in die NG Kerk te soek, hoe kan 'n gemeente groei, hoe kan ons sy lidmate effektief bedien, hoe kan finansies groei, hoe kan die meelewing groei, hoe kan die betrokkenheid in die kerk groei, hoe kan die impak van die kerk groei, hoe kan die getuienis van die kerk groei, ...

\section{ONTWIKKELING}

In aansluiting by Balswick en Morland (1990:28-34) het ons uit die gesprekke met lidmate in die ooste van Pretoria, die volgende waardes herken:

Die inherente waarde van die individu

Vryheid van die individu 
> Gelykheid in behandeling en geleenthede

$>$ Harde werk en 'n beroepsgesentreerde uitkyk op die lewe

$>$ Klem op bruikbaarheid en nuttigheid

$>$ Doeltreffendheid

$>$ Vooruitgang

$>$ Kompetisie

$>$ Materiële voorspoed

$>$ Fisiese en emosionele gesondheid

Hierdie waardes sou ook onder die volgende hoofde saamgevat kon word:

\subsection{Leiers en leierskapstyle}

Soos mens dit sou verwag, speel gemeenteleiers ' $n$ belangrike rol in die kerklike toneel in die ooste van Pretoria. Een gemeente, wat bekend staan vir ' $n$ meer eietydse benadering, se predikantespan het ' $n$ aantal jare gelede ' $n$ besoek aan Amerika gebring, waar hulle beïndruk is deur die nuwe benadering in daardie gemeentes:

"Ons het in ons gemeente, as ek my nou net kan beperk tot ons gemeente, het ons nou seker veertien, vyftien jaar gelede, het ons begin met vernuwing, of gemeentebou, soos die term daai tyd na vore gekom het, en dit is eintlik begin deur ' $n$ klompie van die predikante wat op Malan Nel se studietoer na Amerika gegaan het, en teruggekom het met ' $n$ groot opgewondenheid. Ons het begin inisiatiewe neem rondom gemeentebou en in die hele gemeentebouproses, in alles wat gedoen en gepraat en besluit is, was die uitgangspunt gewees dat die erediens, is die hart van gemeentewees. So uit die aard van die saak het ons baie dinge gedoen rondom die erediens. In daardie selfde tyd het die ou gebruik om een maal elke maand rondom die kategismus te preek, het begin in die slag bly. Wat gebeur het, is dat viole is ingebring, en musiekinstrumente is ingebring in die erediens, dit was maar regtig, ek dink nie ' $n$ grondige besinning oor erediensvernuwing nie, dit was op grond van wat gesien is in Amerika, het ons nuwe dinge uitprobeer hierso. Sekere goeters is maar net gedoen omdat dit na goeie gebruike gelyk het wat 'n erediens sou kon anders maak as wat dit tradisioneel was”.

Hulle het gesien dat daar in elkeen van die gemeentes wat hulle besoek het ' $\mathrm{n}$ persoon was met ' $\mathrm{n}$ persoonlikheid wat mense angetrek het. Daardie persone se persoonlike eienskappe (charisma, leierskap, ens) het, in kombinasie met hulle teologiese inslag, bygedra tot die sukses van hulle gemeentes se bediening. Met hulle terugkoms het hierdie predikantespan vir mekaar gesê dat nie een van hulle so 'n persoonlikheid het nie. In ' $n$ lang proses het hulle saam begin strewe na 'n egte verhouding met die Here. Hulle het ook baie eerlik gekyk na hulle 
onderskeie gawes en sterk en swak punte, en gekyk hoe hulle mekaar in die bediening van die gemeente kan aanvul. Hulle benadering erken en weerspieel die verskeidenheid van die lidmate in hulle gemeente se gawes en spiritualiteite. Dit was daarom vir hulle belangrik om voortdurend te luister na wat die lidmate sê. Deur 'n gemeentekonferensie te hou, en deur dit op te volg met jaarlikse konsultasies wat oor 'n breë vlak met die gemeente se leiers gevoer word, kon hulle die lidmate betrek by die koersbepaling in die gemeente. Vandag is daar min spanning - die gemeente het elke Sondag verskillende eredienste wat voorsiening maak vir die verskillende groeperinge in die gemeente.

Hierdie waarneming word deur Gerkin (1991:119-121) bevestig. Hy vra hoe funksioneer die metafoor "gemeenskap" in hedendaagse hoofstroom Amerikaanse gemeentes? Sy antwoord is dat dit meestal rondom die predikant as simboliese leier van die gemeenskap sentreer. Hoe nader die lidmaat aan die "inner circle" rondom die predikant leef, hoe meer ervaar daardie lidmaat "gemeenskap". Dit lei daartoe dat gemeentes gevorm word uit mense wat hulle gelyksoortigheid meer koester as wat hulle hulle diversiteit koester. Hulle identiteit lê daarin dat hulle aan dominee so en so se kerk behoort. (Een lidmaat vertel aan my die verhaal van die dag toe hulle gemeente se nuwe kerkgebou ingewy is. Die seremoniemeester het glimlaggend gepraat van "dominee... se kerk".) Die gemeente het vir hulle ' $n$ veilige ruimte geword waar hulle beskerm kan word teen die pluralisme van die wêreld waarbinne hulle werk en leef.

Die volgende verhaaltjie sê nog meer oor die rol van gemeenteleiers. ' $n$ Lidmaat wat uiteindelik saam met ' $n$ groep ander lidmate hulle gemeente verlaat het, vertel dat hy aanvanklik baie onbetrokke was in sy gemeente. Dit was onder andere weens die, soos hy sê, charismatiese styl in die gemeente. Toe hy op 'n stadium ' $n$ persoonlike krisis ervaar, het hy by een van die gemeenteleiers berading ontvang. Uit sy verbintenis met hierdie leier het hy in aanraking gekom met ander lidmate wat ook soos hy gevoel het. Uiteindelik was hierdie groep lidmate die kern van ' $n$ groep wat saam met die pastorale berader die gemeente verlaat het om 'n nuwe gemeente te stig.

Die volgende verhaaltjie oor die kerk se leierskap is ook betekenisvol. Dit gaan oor 'n predikant wat as gevolg van werksomstandighede aan erge depressie gely het:

"In daardie tyd in die hospitaal was daar seker agt dominees by nege verskillende kere by my gewees, waarvan daar twee vir my uitstaan, en twee wat gevoel het, een is ...., omdat ek geweet het hy verstaan wat die kwessie is en hy verstaan wat pyn is want hy het self pyn beleef. Die ander ene was ' $\mathrm{n}$ dominee wat self verskriklike depressie het en self ' $n$ verskiklike stryd beleef 
het en pyn beleef het, en swaarkry beleef het. Hulle twee het verstaan wat met my aangaan, en dit het iets vir my beteken. En dit het ook net bevestig dat, of vir my bevestig, die gevoel wat ek gehad, persepsie wat ek gehad het dat die kerk nie regtig sy mense verstaan nie. Die kerk is 'n groot struktuur, en die kerk is blink, en die ouens kom met hulle blink pakke en geleerde stories by die sinodes aan en hulle praat goed wat ek amper nie verstaan nie, hoe moet die lidmate dit verstaan. Ek sit en luister na preke, en dan dink ek aan my kinders wat hier langs my sit en nie 'n woord verstaan van wat daardie dominee daar sê nie want sy woorde is so groot dat ek amper nie verstaan nie, hoe moet hulle verstaan."

Samevattend blyk dit dat leiers een van twee benaderings kan volg. Dit kan gebeur dat leiers ' $n$ visie het van hoe die gemeente moet wees, en dan die gemeente in daardie rigting verander en (be)stuur. Dit is duidelik nie sulke leiers se bedoeling om lidmate in 'n rigting te dwing nie, maar tog word gepraat in terme van woorde soos "bekering", "uit jou gemaksone skud”, "ons moet net aan die Skrif gehoorsaam wees", ens. Nie alle lidmate val by so ' $n$ benadering in nie, en verkies dan om die gemeente te verlaat, soos wat met baie mense gebeur het. Aan die ander kant is daar gemeentes wat die verskuiwing so bestuur dat daar steeds ruimte geskep word vir lidmate wat nie die verskuiwing goedkeur en daarmee wil saamgaan nie. Die ruimte bestaan in eredienste waarin sulke mense geakkommodeer word, gesprekstrukture waar hulle steeds hulle stem kan laat hoor, besoeke deur leiers aan hierdie mense waar hulle kan ervaar dat hulle steeds belangrik is vir die gemeente.

\section{2 “Amerikaanse” versus "Europese” lewensgevoel}

"Ek dink baie van die sukses is toe te skryf aan die persoon se persoon, aan sy styl van doen, wat charismaties is. Sy spiritualiteit word bepaal deur sy persoon. Ek dink dis sy persoon. Hy het ook blootstelling gehad aan die Amerikaanse konteks ...”

So beskryf iemand die situasie in 'n spesifieke gemeente in die ooste van Pretoria. In 'n ander gemeente vertel ' $n$ lidmaat dat sy baiemaal van die dienste in Lewende Woord en Hatfield Christian Centre bywoon. Sy het aanvanklik baie skuldig gevoel daaroor, totdat sy gaan kers opsteek het by ' $n$ besoeker uit Amerika wat in hulle gemeente se erediens kom preek het. Sy woorde aan haar was: "as mens by die bure gaan uiteet, beteken dit nie dat jy by hulle gaan bly nie". Sy stel dit so: "Ek kerk in my eie gemeente, en ek lekker in ander gemeentes". Sy en haar man is ook ten nouste betrokke by Campus Crusade, ' $n$ beweging wie se oorsprong in Amerika is. ' $n$ Lidmaat uit ' $n$ ander gemeente vertel entoesiasties oor sy Bybelstudie. Hy gebruik graag die boekies van Kaye Arthur, ' $n$ Amerikaner. 
' $n$ Predikant wat baie gekant is teen die verskuiwing in spiritualiteit, vertel opgewonde van sy ervarings in Nederland:

“... dit is eintlik wat Europa presies beleef in hierdie sogenaamde postmoderne era, met die ontdekking van die klein kerk, die klein ervaring, ... My slotsom is dus die volgende. Aan die einde van die dag is die charismatisering van die kerk ' $n$ laaste desperate poging om 'n modernisties kerk beeld in stand te hou, 'n kerk wat sou kon draai om 'n groot gebou, ' $n$ grote fisies aanwesigheid, om ' $n$ groter struktuur, om ' $n$ groter... dit is die laaste krampagtige poginkie om die kerk in stand te hou, en uit ons kontak met Europa en met ons eie gemeente, het ek agtergekom dat dit gaan nie werklik waar die tye kan keer nie. Ons moet die vreugde van 'n egte gereformeerde herlewing... asof ek wil probeer soek na 'n verhouding met God wat God voer met pelgrims, met reisigers. Dit is eintlik wat Europa presies beleef in hierdie sogenaamde post-moderne era, met die ontdekking van die klein kerk, die klein ervarings, met onsekere mense, bang mense, siek mense, ou mense, die sondaars as te ware van die wêreld, en in die opsig het ons gewoon, is ons gewoon in " $n$ hoek gedwing om dit te kon herontdek."

' $n$ Lidmaat uit ' $n$ ander gemeente beywer hom sterk vir die gebruik en die behoud van die Europese kerkmusiek wat uit die tyd van die hervorming kom. Hy raak bewoë as hy vertel wat die nuwe liedboek vir hom beteken. Hy vertel dat hy ' $n$ musiekversameling het uit letterlik alle genres (underground heavy metal, Beatles, ens) en wêrelddele, en dat selfs sy vrou graag na gospelmusiek luister, maar hierdie musiek "help my nie om by my innerlike belewenis van God uit te kom nie”.

Ons besef dat die verwysing na "Amerika" en "Europa" baie veralgemenend is en in baie opsigte ten onregte gebruik word. Dit kom egter uit die verhale van die gespreksgenote na vore en bestaan dus as persepsies van mense. Dit verteenwoordig duidelik ' $n$ spanningslyn wat aan die suidpunt van Afrika tot 'n eie unieke ontknoping (klimaks) kan kom.

\subsection{Party mense vra na verandering, ander weerstaan alle verandering}

Aan die woord is ' $\mathrm{n}$ dominee:

"Ek dink die oorspronklike vernuwende gedagtes was maar net ' $n$ besef dat ons het begin stagneer in formalisme. Ook wat die liturgie aanbetref. En dat ons dinge maar net doen omdat ons dit nog altyd gedoen het. Ons het nou maar skuldbelydenis gedoen, en geloofsbelydenis gedoen en ons het ' $n$ bietjie vasgeval in formalisme. Jy het nie die belewenis, die ervaring van dit beteken vir jou iets nie. En ek dink wat gebeur het met die Amerika besoeke, want daar was toe nou, die predikante het uiteindelik in verskillende jare het hulle soontoe gegaan. En ek dink wat gebeur het is die mense het daar agtergekom, 
die eredienste, die mense beleef en ervaar hule eredienste intens. En ek dink die oë het oopgegaan vir ander liturgiese elemente, wat vir daai mense sinvol is. Wat oorgekom het, aanvanklik was ek dink ' $n$ klomp gimmicks. Jy weet 'n paar skuiwe is gemaak. En die besinning, diepgaande besinning, het algaande plaasgevind. Dit was ' $n$ lang proses gewees. Maar dit is menslik. Jy weet, mens verstaan dit.

Dis hoekom ons toe nou dadelik ' $n$ digitale bord gekry het en toe nou later die data projektor gekry het, maar ek dink ook dit lei aan die een kant daartoe dat mense gemaklik raak. Die verbruikersmentaliteit. En ek dink dat hulle daarom baie keer maklik getrek word na kerkgeboue wat mooi lyk, wat gemaklik is, wat ' $n$ goeie aanbieding het, ons probeer ' $n$ goeie aanbieding daar gee vir ons lidmate, maar ek dink nie net 'n goeie aanbieding nie, maar ook ' $n$ goeie geestelike belewenis - ons wil ' $n$ proses fasiliteer waar mense regtig ' $n$ goeie geestelike belewenis kry. Maar die skeidslyn is nie altyd so duidelik nie. Nie vir ons nie, en ek dink vir lidmate minder. Ek dink dis hoekom dit vir hulle partykeer aanloklik is om in 'n kerkgebou te sit wat gemaklik is. Jy weet, wat vir hulle dinge aanbied wat in lyn is met wat hulle aan gewoond is in die wêreld. Dis hoekom ons ook binne in ons kerkruim groot veranderings, strukturele veranderings aangebring het. Om aan te sluit by mense se behoeftes en verwagtinge”.

Maar nie almal deel in hierdie strewe nie. 'n Ouderling vertel:

"Ek was natuurlik een van die ekstreme ouens gewees wat nie veranderinge ten goede sien nie. Totdat ek natuurlik nou sien in Psalm 63, watter psalm, waar Hy nou vir jou sê jy moenie 'n heining om jou kerk bou nie, nê? Ek dink dis wat, 65, 63, 65, waar Hy sê: Moenie die mense weghou wat daarvan wil kom nie. Jy kan dit nie doen nie, jy moet beginne ligter raak. Ek gee dit toe. En ek aanvaar dit ook so.”

Daar is ook ' $n$ omgeegroepleier (van wie mens aanvanklik sal verwag dat hy ten gunste van verandering is) wat vertel:

"Ek self het op ' $n$ punt gekom in die gemeente wat ek saam met my omgeegroep gereageer het om te sê dinge loop nou verkeerd. Dit is regtig verkeerd. Ons sal ons eie rol in God se koninkryk ontken as ons nie reageer nie. Toe het ons ' $n$ brief opgestel en dit vir die kerkraad gestuur."

Hierdie verhale kan vermenigvuldig word. Mense beleef soms die verandering so negatief dat hulle met baie pyn uit hulle gemeentes bedank. Een dominee vertel hoe die predikant by wie hy self belydenis van geloof afgelê het, en wat na sy aftrede in hierdie dominee se gemeente kom woon het, besluit het om by 'n ander gemeente te gaan inskakel. Hy kon gladnie met die veranderings saamleef nie. Dieselfde pynlike situasie spreek uit hierdie ouderling se vertelling: 
"Jy het seergekry in die begin. Jy kry seer in die begin, nè. Kyk, ek kan byvoorbeeld nie in die ouetehuis hierdie soort van ding gaan doen nie. Wat nou tussen jongmense gebeur in sekere kerkdienste, nè. Nee, my maggies, hulle sal mal word. Ons is nog konserwatief. Ons glo daaraan, as jy daar ingaan, nou, kyk, ek was verskriklik afgeskiet gewees omdat ek eendag die woord, hierdie, hm, die kerk is heilig, man! Vir my. Was ek afgeskiet daaroor."

Sal die verhaal van hierdie navorsing kan bydrae tot ' $\mathrm{n}$ beter situasie waarin die kerk in die toekoms meer sensitief sal wees vir hierdie soort pyn?

\section{VERHOUDINGS EN DIENSLEWERING}

Tussen die verskille en die pyn deur is daar tog ' $n$ gemeenskaplike element in die ooste van Pretoria. Mense deel in ' $n$ soeke na betekenisvolle verhoudings en ' $n$ gesindheid van dienslewering. Vernuwing gaan baiemaal gepaard met ' $n$ sterk groepbediening in die gemeente, waar lidmate in groepe ingeskakel word wat mekaar in hulle geloofslewe en andersins sterk ondersteun. Die mooiste verhaal wat ek teëgekom het, was toe ek een egpaar besoek wat beswaard voel oor al die veranderinge in hulle gemeente. Hulle het my gevra om ' $n$ bietjie te wag voordat ons met ons gesprek kan begin, want hulle is besig met ' $n$ vergadering met ' $n$ ander egpaar oor ' $n$ spesifieke sendingaksie. Wat was my verbasing groot toe ek uitvind die ander egpaar is mense wat die veranderinge in hulle gemeente sterk propageer en bevorder, en dit trouens op ' $\mathrm{n}$ stadium sterk oorweeg het om oor te gaan na Lewende Woord gemeente toe. Hierdie twee egpare het lank aan dieselfde omgeegroep behoort, en pak steeds baie projekte saam aan.

' $\mathrm{n}$ Dominee in ' $\mathrm{n}$ gemeente waar verandering baie teëgestaan word, vertel dat sy gemeente spesifiek gekies het om ' $n$ tradisionele gemeente te bly. Hy is op daardie voorwaarde na hulle toe beroep. Sy taak is om as herder vir die mense te sorg en vir hulle om te gee.

'n Omgeegroepleier in 'n sogenaamde "charismatiese" gemeente vertel dat die hoogtepunt in sy geloofslewe was toe hulle omgeegroep honderde mense in die weste van Pretoria op 'n gratis maaltyd van wildsvleis, rys en slaai getrakteer het.

Hierdie punt maak die verhaal oop. Ons kan nou verder gaan. Die verhaal van spiritualiteit in die ooste van Pretoria het nie vasgeloop nie!

\section{KLIMAKS}

Mense sê dat God tans in die ooste van Pretoria werk. Is dit so? By al die mooi waarvan ons gehoor het, is daar ook pyn, skeuring, en stryd. Is dit God se werk? Hoe kan hierdie verhaal voortgaan sonder die pyn en die 
stryd? Almal sal saamstem - om kant te kies, sal net nog meer verwydering bring.

Vir ons het dit tog algaande duidelik geword dat, ten spyte van die verdeling en pyn, daar ook sterk ooreenkomste tussen verskillende gemeentes en gelowiges bestaan. Mens sou dit kon beskryf as die positiewe waardes wat tog soos 'n goue draad deur die verhale loop.

\section{AANBIDDING}

Om ' $n$ erediens in enige van die gemeentes in die ooste van Pretoria by te woon, is normaalweg ' $n$ belewenis. Die liturgiese leiers doen besondere moeite. Elke detail word fyn beplan, en as deel van 'n betekenisvolle geheel aangebied. Almal wil in die eredienste vir God aanbid. Party gemeentes doen dit stil en stemmig, met musiek wat oor geslagte heen gevorm het aan ons lidmate se geloofslewens. Die teologiese uitgangspunt is God se heiligheid, wat weerspieël word in 'n erediens wat totaal en al anders is as die wêreld waarin die mense van Maandag tot Saterdag leef. Ons beleef by hulle iets van die gewyde tempeldiens uit die Ou Testament, met ryk simboliese voorstellings en liturgiese gebare vol betekenis. Die gang van die eredienste is bekend aan die deelnemers almal kan hulleself daarin tuis voel en in God se heiligheid sekuriteit vind.

Ander gemeentes beklemtoon die uitbundige vrolikheid van ' $n$ Dawid wat voor die ark uit dans en van 'n melaatse wat na Jesus hardloop om te kom dankie sê vir sy genesing. Die eietydse musiek vertel dat God vir die mens van vandag omgee en ernstig is oor ons behoeftes. Die prediking is aktueel, en beklemtoon beide dit wat God vir die mens gedoen het en dit wat die mense uit dankbaarheid vir God kan doen.

God is in elke erediens teenwoordig. Dit is wat Hy beloof het. Gemeenteleiers en lidmate kan mekaar help om dit so te ervaar.

\section{SORG}

Egte spiritualiteit begin in die erediens en in die binnekamer, vanwaar dit vloei na die manier waarop die lidmate van die gemeente teenoor mekaar optree. God gee die gemeente se lidmate aan mekaar as geskenke geskenke wat mekaar vashou en vir mekaar sorg (Carrol 2000:91-94). Geskenke dryf mekaar nie uit omdat hulle verskillende tale praat nie mens kyk nie ' $n$ gegewe perd in die bek nie! Leiers en kerkrade kan hierdie verhaal verder skryf deur hulle lidmate te help om mekaar te verstaan en na mekaar te luister. As dit gebeur, word gemeenteprogramme verander. Struktuur volg immers op visie. 


\section{DIENS}

Kan ek ' $n$ mooier verhaal as die een hierbo vertel, van die mense wat deur hulle dominee as twee teenpole van spiritualiteit beskryf is, maar hulle werk saam aan ' $n$ sendingprojek? Egte spiritualiteit versand ook nie in die verhouding tussen lidmate alleen nie - dit stroom na die wêreld. Dit laat mense vergeet dat hulle gister nie kon saamsing nie. Hulle kan dit vergeet, want die nood wat voor hulle oë lê, is groter as gister se verskille.

\section{VOORLOPIGE GEVOLGTREKKINGS}

Na ons as navorsers se interaksie met die aksie en aksieveld in die ooste van Pretoria, het ons met huiwering, maar tog met oortuiging die volgende sewe konklusies geformuleer. Op 22 Augustus 2002 het ons dit by wyse van ' $\mathrm{n}$ ope konferensie wat deur die Sentrum vir Voortgesette Teologiese Opleiding (SEVTO) van die Universiteit van Pretoria, aangebied is, aan ongeveer 75 predikante van die NG Kerk voorgelê. Hulle was gevra om hierdie sewe konklusies in kleingroepe te bespreek en daarop te reageer.

Die terugvoer was oorweldigend positief en instemmend. Op grond van daardie terugvoer is sommige formulerings effens verander. Daar was ook twee kritiese stemme uit die gehoor. Die een persoon was nie gelukkig met die navorsingsparadigma en -metodiek nie; die ander persoon was oortuig daarvan dat ons te negatief reageer op die voorspoedkultuur in die ooste van Pretoria. Hy is self ' $\mathrm{n}$ dominee van een van die "sukses"-gemeentes en het gevoel dat daar nie genoeg melding gemaak word van die offervaardigheid en rentmeesterskap wat daar ook heers in hierdie ryk gemeentes nie. Die deernis en sorgsaamheid ten opsigte van die wat minder het, behoort ook vermeld te word. Hierdie gemeentes is volgens hom ook suksesvol omdat hulle aansluit by ' $n$ jonger dinamiese kultuur en ook in staat is om die mense in hierdie deel van die stad intellektueel te ontmoet en op te lei as leiers.

Ons wil hier ook erkenning gee aan die feit dat baie lidmate in al die gemeentes in die ooste van Pretoria (m.a.w. nie net in die sogenaamde "suksesvolle" gemeentes nie) juis in navolging van Christus se dienskneg gestalte ' $n$ passie toon vir die situasie van onbekeerde en minderbevoorregte mense. Ons het ' $n$ verstommende offerbereidheid teëgekom by lidmate wat lang ure en baie geld spandeer om mense se nood te help verlig. Ons is oortuig dat dit, eerder as die verskillende spiritualiteits-keuses wat gemeentes gemaak het, meer beklemtoon moet word in die kerklike gesprek in die ooste van Pretoria.

Met alles in-ag-genome, formuleer ons die volgende as voorlopige konklusies van hierdie navorsingsverhaal: 
1 Die verhale het duidelik gewys dat elke gemeente die Bybel se boodskap oor spiritualiteit en oor gemeentewees vertolk in die lig van wie hulle self is. En daardie identiteit word ook bepaal deur die gemeenskap waarbinne hulle leef. Dit is nie verkeerd dat dit so is nie, maar die vraag kan tereg gevra word of die profetiese stem van die kerk nie ook die lig moet laat val op daardie aspekte van die samelewing (heersende diskoerse) wat verdeel en verslaaf nie. Voorspoed, sukses, vooruitgang, materialisme, snobisme en die verbruikersmentaliteit het gelei tot mense wat seergekry het. Ons indruk is dat die fokus van gemeentes se spiritualiteit soms eensydig op persoonlike belewenis is, terwyl die kwaad wat in sisteme en diskoerse aanwesig is, nie aangespreek word nie. Carrol (2000:88) maak die ter sake opmerking dat die evangelie nie altyd "seeker friendly" is nie: "It is not simply about feeling good, or being entertained, ... It is not a road to prosperity, as is the not-sosubtle message of some of the new-style churches”. Die Skrif word soms oppervlakkig benut net om mense se individuele vroomheid te bevorder, terwyl hulle nie gehelp word om die diepere Christelike waardes te herontdek nie.

2 Nie net mense kry seer nie, ook gemeentes. Die kerklike toneel is in baie opsigte vergelykbaar met een van die vlooimarkte, waar die mense van die ooste van Pretoria so graag koop. Gemeentes is soos stalletjies wat teen mekaar wedywer om die beste resultate te behaal. Die gevolg is ' $n$ ongesonde kompetisie tussen gemeentes met sommige wat sleg verloor. Die kompetisiegees wat so eie is aan die voorspoedskultuur word kritiekloos deel van die kerkkultuur. Daar heers nie 'n gees van samewerking tussen kerke en gemeentes nie, maar een van wedywering

3 Die kerk is veronderstel om uit die Bybel te leef en daarom dit wat Jesus Christus vir die wêreld kom doen het, te vergestalt. Hy was dienskneg by uitstek. Doen die kerk genoeg moeite om nie net vir suksesvolle mense kerk te wees nie? Ons het in die loop van die navorsing bekommerd geraak oor die mense wat deur die blink van die voorspoedkultuur gemarginaliseer word. Al lyk alles op die oppervlakte so voorspoedig, is daar ook die pyn van dié wat nie so suksesvol is soos wat die algemene diskoers wil voorgee nie. Is die kerk in die ooste van Pretoria ook daar vir húlle? Is die algemene 
styl van die kerk nie geneig om mense wat nie by die heersende kultuur inpas nie, te marginaliseer?

4 Daar is lidmate in die ooste van Pretoria wat hulle gemeentes beleef as wêreldvreemd. Die gemeentes word as "suksesvol" gesien, maar tog binne 'n eie na binne gerigte kerklike subkultuur. Dit is asof sulke gemeentes met hulle gebruike en gewoontes kommunikeer dat hulle nie omgee vir die situasie waarin hulle lidmate elke dag leef nie. Die "sukses" wat hulle Sondae in die erediens beleef, word nie vertaal in die praktyk van die week nie. Die kerk in breë verband het sekerlik ook 'n roeping om sulke gemeentes te begelei om saam met Jesus in hierdie wêreld mens te word. "If we accept the incarnational principle, then we may be much more open to expressions of faith and practice that, from a high aesthetic, would be considered tacky or lowbrow but that speak to the needs and experiences of people in the congregation" (Carrol 2000:89).

5 Is die sogenaamde "nuwe hervorming" wat tans soveel opslae in die dagblaaie maak nie ook 'n poging van lidmate en teoloë om kerklike tradisies en besluitnemingsprosesse wat nie sensitief genoeg is vir mense se lewenswêreld en behoeftes nie te dekonstrueer en sosiaal-konstruksionisties te vervang nie? Ons indruk is dat die deelnemers aan hierdie nuwe beweging ook goed verteenwoordig is in die ooste van Pretoria. Die vraag bestaan of hierdie mense met hulle unieke geloofservarings nie deur die populêre voorspoedgerigte massagodsdiens gemarginaliseer word nie? Die indruk bestaan dat gemeentes suksesvol kan wees in terme van sendinguitreike en ander projekte, maar onsuksesvol in die stimulasie van teologiese volwassenheid.

6 Die kerk en die teologie het sekerlik ' $n$ taak om mense in hulle spiritualiteitsvorming en geloofsbelewenis by te staan. Mense druk hulleself in ons tyd al hoe meer uit in terme van beelde en metafore. Die versoeking is dat gemeentes die metafore van die gemeenskap waarbinne hulle leef onbewustelik en kritiekloos napraat, sodat die evangelie dan ' $\mathrm{n}$ verkoopsproduk word, gemeentes soos besighede bedryf word wat winste behaal, en eredienste ' $n$ suksesvolle ervaring word wat in die meeste mense se behoeftes voorsien. Dit het geblyk dat metafore soos "aanbidding”, "sorg" en "diens" gebruik kan word om die eenheid tussen 
gelowiges te bevestig, al verskil hulle oor die verstaan van sommige tradisoneel gebruikte metafore soos "erfsonde" en selfs "verlossing”. Die vraag is of die kerk en teologie bereid en gereed is om mense in die vestiging van meer relevante metafore by te staan sodat hulle hulle verhouding met God en met medegelowiges kan uitdruk en verder ontwikkel?

7 Dit het uit die verhale geblyk dat leiers 'n kritiese rol speel in die verhaal van gemeentes se spiritualiteit. Carrol (2000:82) pleit vir 'n refleksiewe styl van leierskap:

... leaders who have been able to discern a need by listening to folks inside and outside the church express their spiritual yearnings; who have been able to imagine new ways of responding to those needs that they believe are consistent with the gospel; and who have been able to coalesce others around that vision, mobilize the congregation's resources, and help the congregation embody the vision in congregational practices.

Maar sulke leierskap kom nie vanself nie. Ook hier kan die kerk in breê verband 'n groot rol speel. Leiers moet alreeds in hulle opleiding hiervoor toegerus word, terwyl leiers wat reeds in die praktyk van die bediening staan voortdurende begeleiding en ondersteuning nodig het.

\section{Literatuurverwysings}

Balswick, J O en Morland, J K 1990. Social Problems. A Christian understanding and response. Baker Book House: Grand Rapids, Michigan..

Carrol, J W 2000. Mainline to the future - Congregations for the $21^{\text {st }}$ century. John Knox Press: Westminster.

Ceglowski, D 2000. Research as relationship. Qualitative inquiry, 6(1), 88-104.

Gerkin, C V 1991. Prophetic pastoral practice. A Christian vision of life together. Nashville: Abingdon Press.

Lieblich, A, Tuval-Masciach, R en Zilber, T 1998. Narrative research. Reading, analysis and interpretation. SAGE Publications: Thousand Oaks, California.

Müller, J, Van Deventer, W \& Human, L 2001. Fiction writing as metaphor for research: A narrative approach. Practical Theology in South Africa. 16(2), 7696.

McCleod, J 1999. A narrative social constructionist approach to therapeutic empathy. Counseling Psychology Quarterly. 12(4) pp 377-395.

Müller, J 2001. Therapy as fiction writing. Ned Geref Telogiese Tydskrif. 2001.

Onderhoud met me Petro Barnard, 26 Februarie 2002. 
Pattison \& Woodward J 1994. Vission of Pastoral Theology: in search of words that resurrect the dead, in: Willows \& Swintow (eds) 2000.

Willows, D \& Swintow 2000. Spiritual dimensions of Pastoral Care. Practical Theology in a multi-disciplinary context. London: Jesica Kingsley Publ. 